\title{
Game bird consumption in Dene communities of the Northwest Territories, Canada
}

\author{
Mylène Ratelle (1), Laurie Haig, Brian D Laird (1) and Kelly Skinner* (1) \\ School of Public Health and Health Systems, University of Waterloo, 200 University Avenue West, Waterloo, Ontario \\ N2L 3G1, Canada
}

Submitted 16 April 2020: Final revision received 10 November 2020: Accepted 5 January 2021: First published online 11 January 2021

\begin{abstract}
Objective: Game bird consumption is an important part of the diet of Indigenous populations in Canada and, as part of country food consumption, is associated with improved nutritional status. The objective of this project was to document the consumption of game birds for Dene First Nations in the Northwest Territories (NWT), Canada.

Design: Participants were invited to complete a FFQ using an iPad to document the types of country foods consumed, as well as consumption frequency and preparation methods, including thirteen types of game birds.

Setting: The project was implemented in nine communities in the Dehcho and Sahtú regions of the NWT, Canada.

Participants: A total of 237 children and adult participants from Dene First Nations in the Mackenzie Valley region of the NWT took part in the current study.

Results: FFQ findings indicated that game birds were frequently consumed in both Dehcho and Sahtú communities. Canada goose and mallard were found to be consumed by the largest number of participants. Five different species (including Canada goose and mallard) were found to be consumed by at least $25 \%$ of participants over the last year. When consuming game birds, most participants reported consuming the meat as well as most, if not all, other parts of the bird. Conclusions: Differences were observed since the last country food assessment in the 1990s in the same regions. These findings increase knowledge of the current Dene diet patterns and support the understanding of diet transition.
\end{abstract}

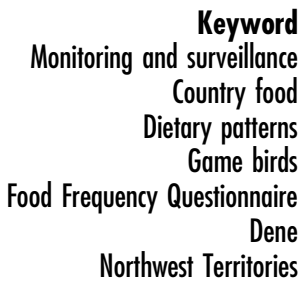

Country food consumption (traditional locally harvested foods from the land and water) is an important part of the diet of First Nations in Canada, who traditionally harvest caribou, moose, fish, game birds, small game and many plants $^{(1)}$. Country foods are integral to the health, wellness and food security of the Indigenous communities within the Northwest Territories (NWT) ${ }^{(1-4)}$. For Indigenous groups in Canada, a dietary transition is underway such that country food harvesting is decreasing while reliance on store-bought food is increasing ${ }^{(4)}$. The primary reason behind this dietary change is thought to be the transition away from traditional subsistence lifestyles, towards the wage economy. Despite this general trend, some residents within particular NWT communities still rely on significant quantities of country foods in their diet. According to the Government of the NWT, $40-50 \%$ of residents in the NWT rely on country food for at least $75 \%$ of their meat and fish; however, this number has been declining since
1999 (5). Larger communities in the NWT have seen a decrease in country food use, due in part to participating in the wage economy leading to a decrease in time and access to country foods, while also having increased access to and financial means for store-bought foods ${ }^{(5)}$. However, most smaller communities primarily have access to low quality, high cost store foods, making sustainable country foods an important resource for the health of these communities ${ }^{(5)}$. Country food consumption promotes the dietary intake of essential nutrients, vitamins and minerals, while reducing the intake of saturated fats, sucrose and carbohydrates, which are often consumed in higher quantities in store-bought food ${ }^{(6)}$. Due to changes in dietary patterns among many Indigenous peoples in northern Canada, country foods now typically make up $<30 \%$ of an individual's total dietary energy, yet despite this lower percentage they still contribute a significant portion of essential nutrients to the $\operatorname{diet}^{(7)}$. Common country foods across the 
NWT include caribou, moose, seals and hare, as well as birds such as ducks, geese, grouse and ptarmigan, fish, and a variety of berries ${ }^{(5)}$.

Aside from the project presented in this paper, a comprehensive assessment of country food consumption among Dene and Metis communities in the NWT was last undertaken over 25 years ago (1993-1995) by the Centre for Indigenous People's Nutrition and Environment $(\mathrm{CINE})^{(8)}$. The findings of the CINE project indicated that game birds make up an important part of the country foods consumed for First Nations, Inuit and Métis in Canada. Our community-based human biomonitoring project was more recently implemented in the NWT in 2015-2018, with the aim of investigating contaminant exposures, nutrition markers and the role of country foods ${ }^{(9,10)}$. Of the ten most consumed country foods in the larger study, two were birds (Canada goose and mallard) ${ }^{(11)}$, highlighting the importance of waterfowl for food security and nutrition, and a need to more closely examine bird consumption.

As part of this larger project, the objective of this paper was to estimate game bird consumption for First Nations in the Sahtú and Dehcho regions in Canada and how it has changed over the past 20 years. Data from a FFQ were used to estimate the average consumption frequency for specific game birds over the 12-month period prior to the participant completing the FFQ. The FFQ results in the current study were subsequently compared with the last available data from the CINE project led by Harriet Kuhnlein in the $1990 s^{(8)}$, in order to document potential changes in patterns of country food preparation and consumption over the past two decades. As the CINE study looked only at bird consumption among adults, the findings of this project have been presented both in terms of all respondents and adult respondents only, for comparative purposes.

\section{Materials and methods}

\section{Study design}

The research team worked with local partnering communities in several Dehcho and Sahtú communities between 2015 and 2018 to develop Community Research Agreements and to implement a human biomonitoring project $^{(9)}$. The local governments provided direction and hired local coordinators in each community to support the project. The FFQ was refined prior to implementation to document country food patterns in these communities $^{(11)}$. The project was implemented in nine communities along the Mackenzie Valley, including two regions: in the Dehcho (Tthets'ek'ehdeli (Jean Marie River), K'atl'odeeche (Hay River), West Point, Deh Gah Gotie (Fort Providence), Ka'a'gee Tu (Kakisa Lake), Sambaa K'e (Trout Lake)) and in the Sahtú (Tulit'a, Deline, and K'asho Got'ine (Fort Good Hope)) in the NWT (Fig. 1). Community research assistants were involved with the recruitment and other aspects of project engagement, and research agreements were signed

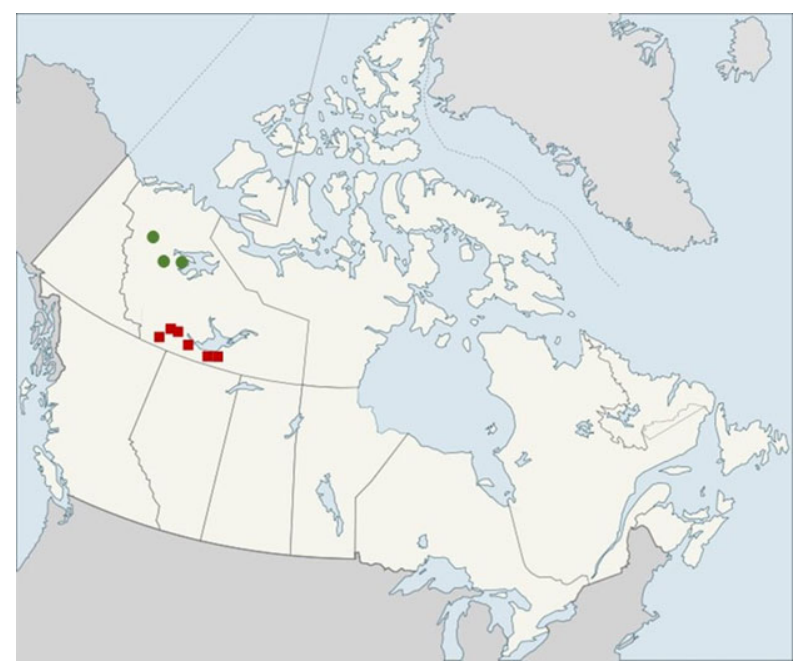

Fig. 1 (colour online) Locations of communities participating in the project (2016-2018), from the ( $\square$ ) Dehcho region and (O) Sahtú region, NWT

with each of the participating communities. Random selection recruitment was combined with word of mouth and poster recruitment, aiming to represent the gender and age distribution of the local population. The larger project, funded by the Northern Contaminants Program, involved the collection of three biological samples (human hair, urine and blood), the administration of two dietary surveys (the FFQ and a 24-h dietary recall) and a Health Messages Survey to characterise knowledge awareness, risk perception and communication preferences ${ }^{(10)}$. Participants had the choice to take part in any number of the six components. Results were returned to participating communities and individuals within 12 months after sampling.

\section{Ethics and consent}

With the assistance of local interpreters and translators (local languages: North Slavey, South Slavey), informed written consent was obtained from participants. Participants aged 6 years and older were invited to take part in the project. Young children were assisted by their parents in completing the FFQ. For those under 18 years of age, the research team described the project both to the minor and to their legal guardian. The minor thereafter was required to confirm their understanding of the project and provide verbal assent, while the parent/guardian of the child was required to provide written consent. In recognition of this time commitment, each participant received compensation in the form of a gift card (e.g., for the local general store).

\section{Food frequency questionnaire}

Participants were asked to complete the FFQ in order to document their country food use over the previous year. FFQ have been used by several research groups to document country food consumption ${ }^{(3,12-17)}$. Our FFQ was administered on iPads through the QuickTapSurvey app. This FFQ gathered 
information about the country foods that participants had eaten over the past year. The FFQ questions asked first about the type of country foods consumed, then what parts and organs were consumed, how often the foods were eaten on average over the last 12 months and how they were prepared. Meal size was also documented, based on photos representing portion sizes. The country foods were categorised into four classes in the survey (fish, land animals, game birds, plants and berries) for which the parts and organs eaten and the frequency, cooking and preparation methods were documented. The FFQ included questions on the consumption of thirteen species of game birds. The FFQ includes up to 319 questions, which are conditional upon previous answers. All of the FFQ were completed in the winter time (November to March). Other details about the FFQ can be found in a previous publication (Ratelle et al., 2020) ${ }^{(11)}$.

\section{Statistics}

Descriptive statistics were calculated using Microsoft Excel 2019. Consumption rates were reported by species (yes/no). Frequencies were reported only for consumers who said 'yes' to at least one of the species. Differences in consumption frequencies were calculated for gender, regions and age groups using the Wilcoxon Mann-Whitney $U$-test in SAS (SAS ${ }^{\circledR}$ Logon Manager, release 9.4, SAS Institute Inc.). The tests were considered statistically significant at $P<0.05$ for a two-tailed test. Since the CINE study only included adults, results reported herein include descriptive statistics from: (i) all respondents and (ii) adult respondents only (i.e., to more directly compare to the previous CINE study).

\section{Results}

\section{Study participants}

A total of $44 \%$ ( $n$ 237) of all the participants from the larger project completed the FFQ. Of these participants, $65 \%$ were from the Dehcho and $35 \%$ were from the Sahtú. Participating individuals were $48.5 \%$ men and $51.5 \%$ women, from 6 to 79 years old, with a median age of 43.5 and an average age of 41.6 years. Further information on participants can be found in Ratelle et al. $2020^{(11)}$. The relatively low response rate to the FFQ might have been due to the addition of other study components, leading to full participation requiring up to $2 \mathrm{~h}$ of time for the participant (e.g., biological sampling, 24-h recall, the Health Messages Survey) ${ }^{(11)}$. As such, it is difficult to assess if the sample is representative of the population.

\section{Bird species consumption}

The most frequently consumed game birds in the last year, and the percentage of participants who reported consuming each of those, are reported in Table 1. The percentage of participants who reported consuming each species ranged from 1 to $57 \%$. Canada goose and mallard were consumed by the largest number of participants ( 57 and
$44 \%$, respectively). Five bird species were consumed by at least $25 \%$ of participants (Canada goose, mallard, spruce grouse, ptarmigan and black duck). A comparison of the rates of consumption between men and women and between different age groups is shown in Table 1 .

There were no differences between genders and regions for the consumption of the most consumed species, Canada goose and mallard. No significant difference was observed for reporting the consumption of cooked Canada goose (men $v$. women: $P=0 \cdot 63$, Dehcho $v$. Sahtú: $P=0 \cdot 11)$. No significant difference was observed for the consumption of cooked mallard (men $v$. women: $P=0 \cdot 44$, Dehcho $v$. Sahtú: $P=0 \cdot 21$ ). No significant difference was observed in the distributions of consumption frequencies reported by men $\left(n_{\text {canada goose }}=52\right.$, $\left.n_{\text {mallard }}=68\right) v$. women $\left(n_{\text {canada goose }}=39, n_{\text {mallard }}=64\right)$ and by Dehcho $\left(n_{\text {canada goose }}=83, n_{\text {mallard }}=71\right) v$. Sahtú $\left(n_{\text {canada goose }}=49, n_{\text {mallard }}=25\right)$. Differences in the number of Dehcho $v$. Sahtú consumers can be attributed in part to the higher percentage of Dehcho respondents to the survey. Consumption of other species or methods was not statistically tested due to small sample sizes ( $<25$ participants). Only the distributions for Canada goose consumption were significantly different for participants under 40 years $(n$ 45) and over/or 40 years ( $n 87)(P=0.001)$, but not significantly different for cooked mallard consumption $(P=0 \cdot 19)$.

\section{Consumption of organs and other parts}

When game birds were harvested, participants reported eating the meat as well as most, if not all, organs and other parts of the animal. For example, when Canada goose was harvested, participants reported eating the meat, gizzard, kidney, heart, liver, eggs and fat. The parts consumed are reported in the online Supplementary Material.

The parts participants reported consuming and the frequency at which they consumed them varied between the Dehcho and Sahtú. For example, $32 \%$ of Dehcho participants reported consuming spruce grouse meat, consuming it on average 1.1 times per week, whereas only $24 \%$ of Sahtú participants reported consuming spruce grouse meat, on average 0.6 times per week. There was also variation seen in terms of the parts of the bird that were consumed. In general, respondents reported consuming organs or other parts of the game birds at a similar or lower frequency than the meat. This was seen, for example, in spruce grouse, sharp-tailed grouse and ptarmigan. The percentage of respondents who reported consuming the meat of the bird was usually higher than the percentage of those who reported consuming other parts.

For most species, participants reported consuming organs including gizzard, kidney, heart and liver. Black duck and long-tailed duck lungs were reported to be consumed by some respondents, as well as wigeon guts. The head was also consumed by some respondents for black duck, mallard, wigeon, Canada goose, snow goose, pintail and swan. Canada goose neck was also consumed. 
Table 1 Percentage of consumers of game birds by species

\begin{tabular}{|c|c|c|c|c|c|c|c|}
\hline \multirow{2}{*}{\multicolumn{2}{|c|}{ Birds consumed }} & \multirow[b]{2}{*}{ Latin name } & \multicolumn{3}{|c|}{$\begin{array}{l}\text { Percentage consuming } \\
(\%)\end{array}$} & \multirow[b]{2}{*}{ Up to 40 years old } & \multirow[b]{2}{*}{40 years old and over } \\
\hline & & & Total & Men & Women & & \\
\hline \multicolumn{2}{|l|}{$N$} & & 237 & 115 & 122 & 96 & 141 \\
\hline 1 & Canada goose & Branta canadensis & 57 & 61 & 54 & 48 & 65 \\
\hline 2 & Mallard & Anas platyrhynchos & 44 & 51 & 38 & 36 & 50 \\
\hline 3 & Spruce grouse & Falcipennis canadensis & 28 & 37 & 20 & 17 & 36 \\
\hline 4 & Sharp-tailed grouse & Tympanuchus phasianellus & 24 & 31 & 18 & 16 & 31 \\
\hline 5 & Ptarmigan & Lagopus sp. & 25 & 32 & 19 & 20 & 30 \\
\hline 6 & Black duck & Melanitta sp/Anas rubripe* & 29 & 31 & 27 & 22 & 35 \\
\hline 7 & Snow goose & Chen caerulescens caerulescens & 19 & 23 & 15 & 9 & 26 \\
\hline 8 & Swan & Cygnus colombianus & 19 & 23 & 15 & 13 & 23 \\
\hline 9 & Pintail & Anas acuta & 13 & 21 & 5 & 7 & 17 \\
\hline 10 & Wigeon & Mareca americana & 6 & 10 & 3 & 4 & 8 \\
\hline 11 & Canvasback & Aythya valisineria & 5 & 7 & 3 & 1 & 8 \\
\hline 12 & Long-tailed duck $\ddagger$ & Clangula hyemalis & 3 & 5 & 2 & 0 & 5 \\
\hline 13 & Fish duck§ & Mergus sp/Lophodytes & 1 & 1 & 1 & 0 & 2 \\
\hline All & Species & & 69 & 70 & 67 & 57 & 77 \\
\hline
\end{tabular}

*The community mentioned that people use the term black duck and black scoter interchangeably. It seems multiple species are encompassed under one local name identified as black duck.

†This bird was referred sometimes in the literature as 'oldsquaw', a name which is still used in some parts of the NWT.

flt seems multiple species are encompassed under one local name identified as fish duck, potentially including red-breasted merganser, hooded merganser and common merganser.

Notably, none of the participants reported consuming any fish duck organs, and only $1-2 \%$ of respondents across groups reported consuming fish duck meat. Among both the Dehcho and the Sahtú, Canada goose gizzard, heart and fat were the most frequently consumed organs overall of all organs from all species, although the order of preference between these three was not the same for both groups (Table 2). The consumption patterns changed between the 1990s and the current study. As mentioned in the previous section, there seems to be a trend for changing consumption patterns over time for both genders and regions. Both for the Dehcho and Sahtú regions, five organs were consumed in the 1990 s by at least $5 \%$ of respondents, while this number increased to six organs from the more recent data in our study (Table 2).

\section{Preparation methods}

A range of preparation methods were documented (cooked, pan fried/deep fried, grilled/roasted/baked, smoked, raw, boiled/soup/stew, smoked/fully dried, smoked/half dried, campfire). The most used preparation methods for the birds consumed by at least $20 \%$ of the respondents (Canada goose, mallard, spruce grouse, sharp-tailed grouse, ptarmigan, black duck) were cooked $(58-71 \%)>$ fried $(33-77 \%)>$ stew $(30-46 \%)=$ campfire $(30-46 \%)>$ roasted $(18-35 \%)>$ smoked $(3-21 \%)$. No participants reported consuming raw game bird meat. The smoked foods consumed by the participants are reported in Table 3. Within these game birds, Canada goose, swan and snow goose were the foods most frequently consumed after being smoked.

The most frequently reported preparation method across species was cooked. The online Supplementary
Material provided reports on the numbers of respondents who consumed each of the species cooked. Canada goose was the most frequently reported cooked species, followed by mallard, black duck and spruce grouse. Dehcho respondents reported consuming several more game bird species compared with Sahtú respondents. Male respondents also reported consuming more game bird species than female respondents. However, for both long-tailed duck and snow goose, the majority of participants who reported eating the cooked bird were from the Sahtú $v$. the Dehcho (75 and $67 \%$, respectively). There was a difference of $8-15 \%$ in the use of the campfire preparation method between men and women for the three most consumed birds (Canada goose, mallard, black duck).

\section{Discussion}

\section{Importance of bird consumption}

Birds are an important food source in many parts of the world and have been for centuries ${ }^{(18)}$. Bird consumption has a very important cultural role in the Dehcho and Sahtú regions. In fact, the community of K'ahbami Tue (Colville Lake) means 'Ptarmigan Net Lake', referring to the traditional method of trapping the bird ${ }^{(19)}$. Birds are important to Dene people as a country food source, along with being a good source of protein, vitamins and minerals $^{(18)}$. Additionally, birds have been identified as a sustainable food source with the potential to improve food security, while the populations of some other country food species, like caribou, are in decline ${ }^{(18,20)}$.

The results of the current study are in line with what was found by other authors in the NWT. A study on country food consumption among the Sahtú and Dene/Métis in 
Table 2 Bird parts consumption pattern changes between CINE study (1993-1995) and current study (2016-2018)

\begin{tabular}{|c|c|c|c|c|}
\hline \multirow[b]{2}{*}{ Categories } & \multicolumn{2}{|c|}{ Dehcho } & \multicolumn{2}{|r|}{ Sahtú } \\
\hline & 1993-1995 - CINE & 2016-2018 & 1993-1995 - CINE & 2016-2018 \\
\hline $\begin{array}{l}\text { Number of organs consumed } \dagger \\
\text { Most consumed bird organs } \ddagger\end{array}$ & $\begin{array}{l}5 \\
\text { 1.Spruce grouse gizzard } \\
\text { 2.Sharp-tailed grouse gizzard } \\
\text { 3.Mallard gizzard }\end{array}$ & $\begin{array}{l}6 \\
\text { 1.Canada goose gizzard } \\
\text { 2.Canada goose heart } \\
\text { 3.Canada goose fat }\end{array}$ & $\begin{array}{l}5 \\
\text { 1.Ptarmigan gizzard } \\
\text { 2.Ptarmigan heart } \\
\text { 3.Spruce grouse gizzard }\end{array}$ & $\begin{array}{l}6 \\
\text { 1.Canada goose heart } \\
\text { 2.Canada goose gizzard/Canada goose fat* }\end{array}$ \\
\hline
\end{tabular}

Table 3 Smoked game bird meat consumed by at least $1 \%$ of the respondents and average frequency of consumption per week by consumer

\begin{tabular}{|c|c|c|c|c|c|c|c|c|c|c|c|c|}
\hline & \multicolumn{4}{|c|}{ Dehcho } & \multicolumn{4}{|c|}{ Sahtú } & \multicolumn{4}{|c|}{ Dehcho and Sahtú (Mackenzie Valley) } \\
\hline & \multicolumn{2}{|c|}{ All respondents ( $n$ 154) } & \multicolumn{2}{|c|}{$\begin{array}{l}\text { Adult respondents only } \\
\qquad(n 125)\end{array}$} & \multicolumn{2}{|c|}{ All respondents ( $n$ 123) } & \multicolumn{2}{|c|}{$\begin{array}{l}\text { Adult respondents only } \\
\qquad(n \text { 83) }\end{array}$} & \multicolumn{2}{|c|}{ All respondents ( $n$ 237) } & \multicolumn{2}{|c|}{$\begin{array}{l}\text { Adult respondents only } \\
\qquad(n 197)\end{array}$} \\
\hline & $\begin{array}{c}\text { Consumers } \\
(\%)\end{array}$ & $\begin{array}{l}\text { Frequency } \\
\text { per week }\end{array}$ & $\begin{array}{c}\text { Consumers } \\
(\%)\end{array}$ & $\begin{array}{l}\text { Frequency } \\
\text { per week }\end{array}$ & $\begin{array}{c}\text { Consumers } \\
(\%)\end{array}$ & $\begin{array}{l}\text { Frequency } \\
\text { per week }\end{array}$ & $\begin{array}{c}\text { Consumers } \\
(\%)\end{array}$ & $\begin{array}{l}\text { Frequency } \\
\text { per week }\end{array}$ & $\begin{array}{c}\text { Consumers } \\
(\%)\end{array}$ & $\begin{array}{l}\text { Frequency } \\
\text { per week }\end{array}$ & $\begin{array}{c}\text { Consumers } \\
(\%)\end{array}$ & $\begin{array}{l}\text { Frequency } \\
\text { per week }\end{array}$ \\
\hline Spruce grouse & 1 & 1.5 & 2 & 1.5 & 0 & - & 1 & 1.5 & 1 & 1.5 & 1 & 1.5 \\
\hline Ptarmigan & 0 & - & 0 & - & 2 & 0.5 & 1 & 0.5 & 1 & 0.5 & 1 & 0.5 \\
\hline Black duck & 1 & $2 \cdot 8$ & 2 & $2 \cdot 8$ & 2 & 0.5 & 3 & 1.6 & 2 & $1 \cdot 6$ & 2 & 1.6 \\
\hline Mallard & 0 & - & 0 & - & 4 & 0.5 & 2 & 0.5 & 1 & 0.5 & 1 & 0.5 \\
\hline Wigeon & 1 & 0.5 & 1 & 0.5 & 1 & 0.5 & 2 & 0.5 & 1 & 0.5 & 1 & 0.5 \\
\hline Canvasback & 0 & - & 0 & - & 1 & 0.5 & 1 & 0.5 & 1 & 0.5 & 1 & 0.5 \\
\hline Canada goose & 5 & 1.4 & 5 & 1.4 & 16 & 0.9 & 12 & 1.0 & 8 & $1 \cdot 1$ & 9 & 0.9 \\
\hline Snow goose & 1 & 0.5 & 1 & 0.5 & 7 & 0.5 & 6 & 0.5 & 3 & 0.5 & 4 & 0.5 \\
\hline Pintail & 0 & - & 0 & - & 2 & 0.5 & 2 & 0.5 & 1 & 0.5 & 1 & 0.5 \\
\hline Swan & 2 & 1.5 & 2 & 1.5 & 7 & 0.5 & 6 & 0.6 & 4 & 0.8 & 4 & 0.8 \\
\hline
\end{tabular}


K'asho Got'ine (Fort Good Hope) and K'ahbami Tue found that black scoter and mallard were the main birds frequently consumed in the 6-month period assessed (May, June, July, August, October and November) in K'asho Got'ine, while in K'ahbami Tue only black scoter was among the most frequently consumed country foods over the 6-month period ${ }^{(21)}$. However, in both communities, Canada goose and ptarmigan were consumed by over $50 \%$ of households when in season, and many people in K'ahbami Tue also consumed merganser (fish duck) when in season ${ }^{(21)}$. Additionally, a FFQ conducted by Batal and colleagues identified the frequent consumption of boiled Canada goose meat, baked ptarmigan flesh and baked black duck flesh in Denendeh (i.e., the western portion of NWT) and the Yukon ${ }^{(12)}$. Canada geese are also an important source of food for the communities of Tuktoyaktuk and Paulatuk in the Inuvialuit Settlement Region, $\mathrm{NWT}^{(6)}$. In summary, based on the available data from the literature and including our study, black scoter, mallard, Canada goose, ptarmigan and fish duck are important game birds for the diet of Dehcho and Sahtú community members in the NWT.

\section{Comparison to country food consumption in the 1990s}

Results from the FFQ, including the list of foods consumed, consumption frequencies and portion sizes, and gender differences, reflect the food behaviour of this Dene population in 2016-2018. These findings can be used to monitor dietary changes over time and provide knowledge to support locally harvested foods to improve food security in the region. A comparison can be made between this project and the CINE project completed in the $1990 \mathrm{~s}^{(8)}$, which used similar survey methods. In 1994, CINE conducted similar surveys on country food consumption in sixteen Dene/ Métis communities in the $\mathrm{NWT}^{(8)}$. During this research, FFQ were conducted in Sahtú and Dehcho communities ${ }^{(8)}$; however, not all of the same communities were interviewed in both our project and the CINE study. In the CINE project, the Sahtú and Dehcho communities which participated were K'ahsho Got'ine (Fort Good Hope), K'ahbami Tue (Colville Lake), Deline, Pehdzéh Ki (Wrigley), Liidlii Kue (Fort Simpson), Tthets'ek'ehdeli (Jean Marie River) and Deh Gah Gotie (Fort Providence) ${ }^{(8)}$, which overlaps with four of the communities in this current project (two in the Dehcho and two in the Sahtú).

In both surveys, participants were asked about their consumption of the same thirteen bird species: spruce grouse (spruce hen), sharp-tailed grouse (prairie chicken), ptarmigan, black duck (black duck and black scoter are used interchangeably by the community members), mallard, fish duck (hooded merganser, Arctic loon), long-tailed duck, wigeon (whistling duck), canvasback, Canada goose, snow goose (wavies), pintail and swan. Both this project and the CINE study found that many organs and parts of the animal other than the meat are not widely consumed in these regions.

None of the communities that participated in the CINE project had birds among their five most frequently consumed country foods across the seasons ${ }^{(8)}$, whereas our study had two birds (Canada good and mallard) among the ten most frequently consumed country foods. However, the CINE report indicates that participants in the majority of the regions (including Sahtú, Dehcho and others) wanted to consume more birds in their diets $^{(8)}$. Several differences were observed between the results of this 2016-2018 study and the CINE study from 1993 to 1995 mainly for the types of organs that were frequently consumed, and the types of birds consumed. Table 4 and Figure 2 show a comparison of game bird consumption between these two studies. The CINE study identified the organs that were most frequently consumed as those from spruce grouse, sharp-tailed grouse, mallard and ptarmigan, while the present study identified only Canada goose organs among the most frequently consumed. As shown in Figure 2, there was increased consumption of the two most consumed species, Canada goose and mallard, in both regions for the current study. In a similar trend, the percentage of people consuming Canada goose and swan more than doubled in both regions since the CINE assessment. Alternately, the third most consumed species of bird, spruce grouse, decreased in consumption over time in both regions. There were also some trends that showed differing consumption patterns between regions. For example, the consumption of pintail and snow goose increased much more in the Sahtú region than in the Dehcho region between the two study periods.

The comparison between the summary descriptive statistics from the two studies suggests several changes in the popularity and/or accessibility of certain bird species. Notably, Canada goose and mallard were among the most frequently consumed species in the current study, with their meat being consumed by $57 \%$ (Canada goose) and $52 \%$ (mallard) of Dehcho respondents and $63 \%$ (Canada goose) and $40 \%$ (mallard) of Sahtú respondents. However, the CINE study reported that only $25 \%$ of Dehcho participants consumed Canada goose, while $28 \%$ consumed mallard, and only $15 \%$ of Sahtú participants consumed Canada goose and 19\% consumed mallard. None of the birds reported in the CINE study were consumed by over $40 \%$ of respondents in the Dehcho or Sahtú; spruce grouse and sharp-tailed grouse meat in Dehcho, and ptarmigan meat in Sahtú had the highest percentages of consumers, between 30 and $40 \%$. Consumption of wigeon, snow goose, pintail and swan meat appeared considerably higher in the present study compared with CINE results. Overall, eight of the thirteen species were consumed more in our recent study for both the Dehcho and the Sahtú regions than 20 years ago. 
Table 4 Comparison between the country food consumption for adults in CINE study (1993-1995) and current study (2016-2018)

\begin{tabular}{|c|c|c|c|c|c|c|c|c|}
\hline \multirow[b]{4}{*}{ Species } & \multicolumn{4}{|c|}{ 1993-1995* } & \multicolumn{4}{|c|}{ 2016-2018† } \\
\hline & \multirow{2}{*}{\multicolumn{2}{|c|}{$\frac{\text { Dehcho }}{(n 217)}$}} & \multirow{2}{*}{\multicolumn{2}{|c|}{$\frac{\text { Sahtú }}{(n \text { 180) }}$}} & \multirow{2}{*}{\multicolumn{2}{|c|}{$\frac{\text { Dehcho }}{(n \text { 125) }}$}} & \multirow{2}{*}{\multicolumn{2}{|c|}{$\frac{\text { Sahtú }}{(n \text { 83) }}$}} \\
\hline & & & & & & & & \\
\hline & $\begin{array}{c}\text { Consumers } \\
(\%)\end{array}$ & $\begin{array}{l}\text { Frequency } \\
\text { per week }\end{array}$ & $\begin{array}{c}\text { Consumers } \\
(\%)\end{array}$ & $\begin{array}{l}\text { Frequency } \\
\text { per week }\end{array}$ & $\begin{array}{c}\text { Consumers } \\
(\%)\end{array}$ & $\begin{array}{l}\text { Frequency } \\
\text { per week }\end{array}$ & $\begin{array}{c}\text { Consumers } \\
(\%)\end{array}$ & $\begin{array}{l}\text { Frequency } \\
\text { per week }\end{array}$ \\
\hline Spruce grouse & 52 & 1.3 & 29 & 0.3 & 32 & $1 \cdot 1$ & 24 & 0.6 \\
\hline Sharp-tailed grouse & 36 & 1.2 & 14 & 0.9 & 30 & 1 & 24 & $1 \cdot 1$ \\
\hline Ptarmigan & 12 & $1 \cdot 1$ & 39 & 0.8 & 22 & 0.8 & 33 & 0.8 \\
\hline Black duck & 21 & $1 \cdot 1$ & 26 & 0.9 & 29 & 0.8 & 33 & 0.9 \\
\hline Mallard & 28 & $1 \cdot 1$ & 19 & 0.5 & 52 & $1 \cdot 2$ & 40 & 1 \\
\hline Fish duck & 2 & 1.9 & 4 & 0.9 & 2 & 0.5 & 1 & 0.5 \\
\hline Long-tailed duck & 5 & 1 & 4 & 0.9 & 2 & 0.5 & 6 & 0.5 \\
\hline Wigeon/whistling duck & 4 & 0.8 & 0 & NA $\ddagger$ & 9 & 1 & 6 & 1.4 \\
\hline Canvasback & 5 & $1 \cdot 7$ & 3 & 1 & 7 & 0.6 & 6 & 1 \\
\hline Canada goose & 25 & 0.8 & 15 & 0.5 & 57 & $1 \cdot 1$ & 63 & 1 \\
\hline Snow goose & 7 & 1.8 & 3 & 0.5 & 12 & 0.8 & 30 & 0.9 \\
\hline Pintail & 5 & 1.9 & 3 & 0.4 & 13 & 0.6 & 15 & 0.7 \\
\hline Swan & 10 & 0.8 & 8 & 0.2 & 23 & 0.9 & 27 & $0 \cdot 8$ \\
\hline
\end{tabular}

NA, not applicable.

*Centre for Indigenous Peoples' Nutrition and Environment (CINE), average summer + winter.

†Reported consumption for our study over a 12-month period (i.e., including summer and winter months).

$\ddagger$ As no Sahtú participants reported consuming wigeon in the CINE study, an average could not be calculated (NA).

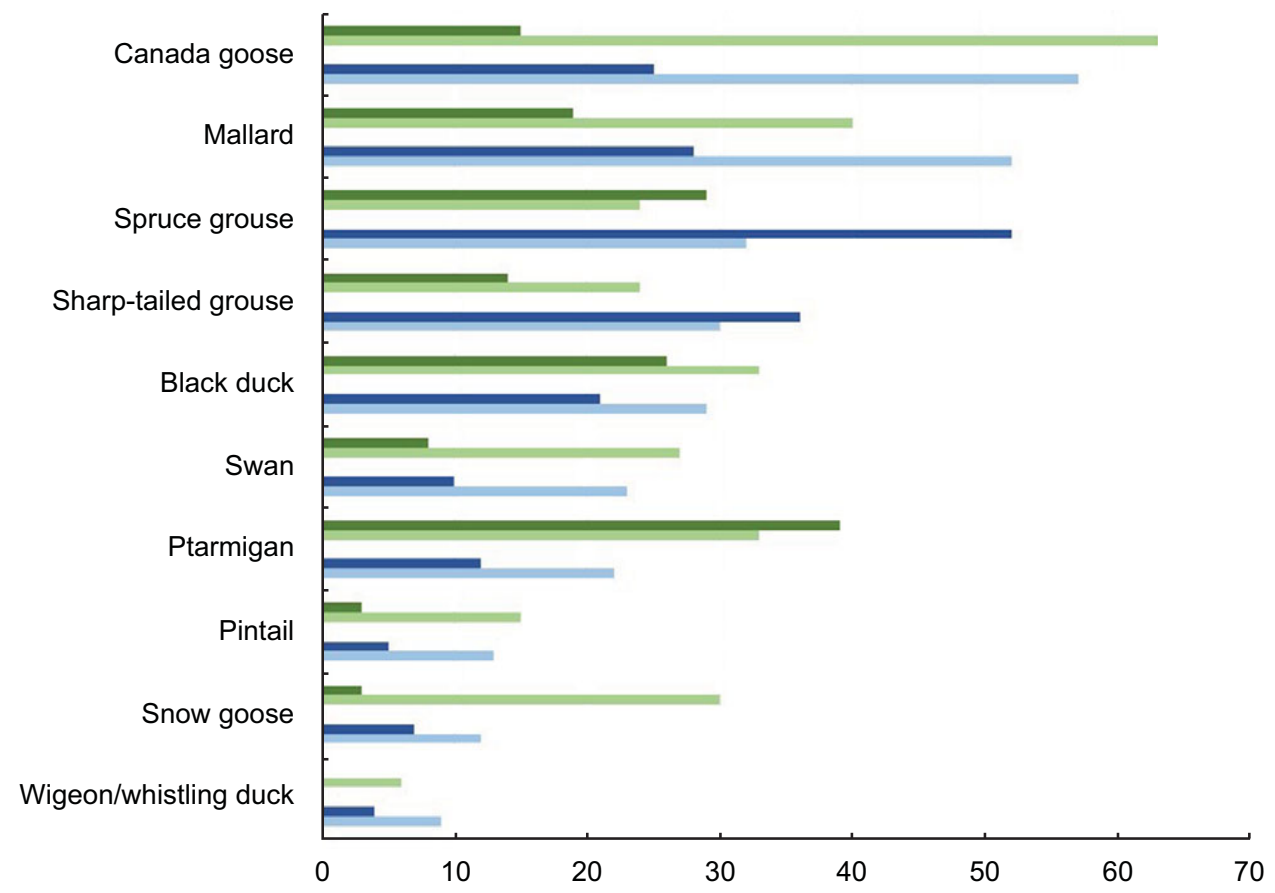

Fig. 2 (colour online) Adult consumers (\%) in 1993-1995 (CINE) a and in 2016-2018 (study) ${ }^{\text {b,c }}$. $\square$, Sahtú-CINE ( $n$ 180); , Sahtú-study

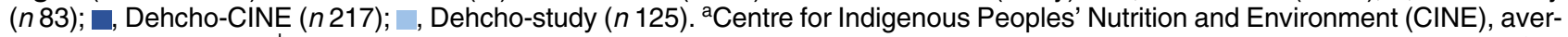
age summer + winter. ${ }^{b}$ Reported consumption for our study over a 12-month period (i.e., including summer and winter months). ${ }^{\mathrm{c}} \mathrm{As}$ no Sahtú participants reported consuming wigeon in the CINE study, an average could not be calculated

There are limitations of comparing these two projects. The CINE used the combination of a 3-month winter and summer FFQ to estimate the yearly consumption ${ }^{(8)}$. However, each of the seasons is potentially associated with different hunting and harvesting patterns and this approach might not be directly comparable to our project, which estimated the consumption of locally harvested food over one full year. Additionally, the CINE only recruited adults, 
which is why we chose to present the data and the total of the results, as well as the adult results only.

\section{Traditional ways of life and bird consumption}

Country food is an important aspect of the preservation of traditional ways of life in many Indigenous communities. The Dehcho and Sahtú participants of the CINE study identified country food as being important spiritually and culturally to their communities ${ }^{(8)}$. However, many Indigenous communities in northern Canada and around the world have experienced a nutrition transition, as diets which once consisted of solely country food before colonial contact now incorporate varying amounts of market food brought in from southern Canada ${ }^{(4)}$. There have also been changes to traditional practices such as hunting, which historically has been done for subsistence and trading ${ }^{(22)}$. While the consumption of game birds varies according to age and gender ${ }^{(11)}$, the consumption of country food is a good indicator of the practice of traditional ways of life by community members.

In our study, the differences in consumption patterns between men and women could reflect differences in gender roles in terms of hunting practices in participating regions of the NWT. While women in Northern communities can traditionally be hunters, frequencies of harvests and type of harvesting activities can differ by gender, as women are often more involved in the larger system of food harvesting, which usually includes the processing (e.g., plucking and singeing of feathers, butchering, filleting of fish, smoking, drying, etc.) of large and small mammals, fish and bird species ${ }^{(23)}$.

In 2013-2014, the Dehcho First Nations initiated a consultation process with communities to assess the perception and impact of a 'return to country foods' and reached out for partnerships supporting this priority, to start discussions about food security issues and climate change.

\section{Environmental factors and climate changes}

Climate and environmental changes have previously been reported to impact traditional hunting and ways of life in the Canadian Arctic. For instance, changes to the timing of sea ice formation and break-up can affect the length and timing of the hunting season ${ }^{(24)}$. Changes to the northern climate and environment are also thought to have an impact on bird harvesting and availability. A 2006 study reported observations among residents in Deh Gah Gotie that the timing of the migration of some birds in that region had changed, and additionally that many new species such as eagles had begun to appear ${ }^{(25)}$. Residents also reported that geese were returning to the community later in the season, which shortened the spring goose hunt by about a week ${ }^{(25)}$. Changes in the timing of the spring break-up of ice, where the break-up occurs either earlier or later than usual, have also impacted the goose harvest, making it more difficult to reach the game birds ${ }^{(25)}$. North of the Mackenzie Valley communities, in the Inuvialuit Settlement Region, residents of Tuktoyaktuk and Paulatuk have observed changes in migratory patterns which they report have resulted in fewer geese in Tuktoyaktuk and a relative increase in geese in Paulatuk ${ }^{(6)}$. Additionally, these communities have been experiencing shorter hunting seasons for geese due to unpredictable spring weather and earlier ice break-up ${ }^{(6)}$.

Furthermore, climate and environmental changes may affect the survival of birds due to habitat loss and degradation, changes to migration and increased risks of disease within bird populations. There is already evidence that changes to weather patterns and climate change have impacted bird behaviour including altering the timing of breeding periods and migration, changes in breeding success such as egg size and nesting success, and changes in population size and distribution ${ }^{(26)}$. For instance in lesser snow geese, habitat degradation caused by breeding grounds overwhelmed by snow geese population growth has created problematic conditions for gosling development ${ }^{(27)}$. Warmer winter and summer conditions have also been found to lower gosling body conditions due to changes to available vegetation and risks of overheating, respectively ${ }^{(27)}$. The presence of parasites combined with warmer summer temperatures may also reduce body conditions, and in some cases survival rates, by disrupting water balance and hydration levels in developing goslings ${ }^{(27)}$. A mismatch in the timing of migration patterns, which are largely driven by photoperiod and circannual rhythms ${ }^{(28)}$, and the timing of plant availability, which is affected by snow melt and growing temperatures, further risks impacting gosling development ${ }^{(27)}$.

\section{Health considerations and contaminant risks}

When discussing the consumption of birds, it should be noted that there may be concerns over the possibility of birds transmitting disease to humans (zoonosis) ${ }^{(18)}$. Although there are concerns that hunters of wild birds may be at an increased risk of avian influenza ${ }^{(29,30)}$, there have been no cases of avian influenza in North America reported to have resulted from exposure to wild birds ${ }^{(31)}$. Additionally, there are some concerns over foodborne illness as a result of country food consumption; however, a recent scoping review of foodborne illness in Canadian Indigenous populations did not identify any studies reporting on illnesses from bird consumption ${ }^{(32)}$. Rather, consumption of walrus, seal, caribou and whale, especially raw or fermented methods that enabled the growth of pathogens, was found to pose an increased risk of foodborne illness ${ }^{(32)}$.

Organochlorine levels in game birds may also be a consideration. A study of organochlorine levels in breast tissue of spring-harvested birds in the James Bay region, compared with previous research in fall-harvested birds, found that levels of organochlorines varied by species ${ }^{(33)}$. For instance, higher levels of polychlorinated biphenyl and 
organochlorines were found in spring-harvested Canada geese compared with fall-harvested geese; however, levels of organochlorines were lower overall in snow geese ${ }^{(33)}$. Still, breast tissue of these birds was found to be safe, as all organochlorine levels identified were below the consumption guidelines for organochlorines in fish and poultry, although other parts of the birds were not assessed ${ }^{(33)}$.

Furthermore, there are concerns about lead exposure in birds as a result of lead shot ${ }^{(34)}$. Although Canada banned the use of lead shot in migratory bird hunting in 1999, lead shot is still permitted for hunting non-migratory birds in some parts of the country ${ }^{(34)}$. One example of this is a lack of regulations prohibiting lead shot in the hunting of upland game birds (such as chukar, pheasant and wild turkey) within provinces, which has led to birds mistakenly ingesting discarded lead pellets ${ }^{(35)}$. Consequently, despite regulations on the use of lead shot in Canada, the USA and many European countries, exceptions made for non-federal jurisdictions, or certain European regulations which only require non-lead shot when hunting over wetlands, continue to pose risks of lead exposure from spent lead shot in the environment ${ }^{(34)}$. Investigation of lead sources is important in the context of these communities as community members have been found to have elevated blood lead levels ${ }^{(36)}$.

\section{Birds and food security}

Country foods are an important part of the food security in Indigenous communities, as traditional Dene/Métis foods are typically lower in fat and energy compared with market foods ${ }^{(8)}$. In the CINE study, it was found that FFQ respondents who reported no country food consumption had lower intakes of protein, $\mathrm{Fe}, \mathrm{Zn}, \mathrm{Cu}, \mathrm{Mg}$ and $\mathrm{P}$ - these nutrients are commonly found in higher concentrations in wild meats than store-bought food ${ }^{(37)}$. Bird consumption in particular contributes to food security. Ducks and other waterfowl are good sources of protein, $\mathrm{Fe}$ and $\mathrm{Cu}^{(6)}$, while Canada goose meat has been found to be a source of high quality protein, $\mathrm{Fe}$ and $\mathrm{Zn}^{(38)}$.

Bird consumption may also be a potential solution to issues of food security. Cooper suggests the potential for the greater use of birds as a food source, including improving upon existing methods for harvesting wild birds and expanding this harvest to new bird species ${ }^{(18)}$. This may be particularly beneficial in circumstances where food and protein sources, in particular, are in short supply ${ }^{(18)}$. For instance, game birds have been suggested as a potential sustainable food source in Southern Africa to address issues of food security in that region ${ }^{(20)}$. It is worth noting, however, that when one species of country food is in decline, not all country foods may be suitable substitutions for a variety of reasons. For instance, in Inuit populations, marine mammals and fish are the main sources of vitamin $\mathrm{D}$ intake, yet if these populations are in decline, substituting an increase in goose or duck intake does not provide the same amount of vitamin $\mathrm{D}^{(24)}$. Alternatively, goose meat has been found to be a suitable substitute for declines in caribou populations as it is able to provide similar levels of protein and $\mathrm{Fe}$ intake ${ }^{(24)}$. Additionally, traditional hunting practices depend on the seasonal variability in the availability of different species, as not all species are in abundance during all times of the year ${ }^{(39)}$. Therefore, game birds may not always be appropriate substitutes as they may not be sufficiently available year-round.

\section{Limitations}

FFQ can be helpful tools for gathering information on which specific foods are most consumed over the course of a year, which can be beneficial for assessing country food intake over time. Although FFQ are a useful and widely used method for assessing dietary patterns, such patterns are difficult to thoroughly assess and there are many limitations of the use of FFQ. Overestimating is a potential risk using FFQ as a survey tool, which is essential to acknowledge in our study as there may have been some overestimation of the frequency of consumption, especially for respondents choosing the response option for infrequent consumption of 'less than once a week' which could mean as little as once or as much as fifty-one times over the course of 12 months. However, the FFQ in the current study was based on the FFQ from the CINE study; thus, the findings between the two studies are comparable, and even if there is some overestimation of bird consumption, the overestimation is probably consistent between the studies. Overestimations would be more pronounced for less frequently consumed items, such as bird organs, rather than the bird meat. The limitations of FFQ, in general, and this one, in particular, are further discussed in Ratelle et al. $2020^{(11)}$.

\section{Conclusions}

Overall, this project provides knowledge on bird consumption in a Dene population and reports the frequency of the country foods consumed in Dene communities in the Sahtú and Dehcho regions of the NWT. The findings show that bird consumption continues to be a part of country food consumption in these regions. Some game birds appear to have become a more important source of food in the communities surveyed compared with 25 years ago, with some changes also seen in the relative frequencies of species consumed. Birds provide a nutritious source of country food which may further address issues of food security.

\section{Acknowledgements}

Acknowledgements: The authors thank the research assistants Sara Packull-McCormick, Victoria Leger and Laura Clappison for their work on the implementation of the questionnaire in QuickTapSurvey and the preliminary data analysis. The research team is grateful for assistance from the following organisations: the Government of Northwest Territories 
Department of Health and Social Services (DHSS); the Dehcho Aboriginal Aquatic Resources and Ocean Management (AAROM); the Dehcho First Nations (DFN), the Sahtú Renewable Resources Board (SRRB); the Sahtú Secretariat Incorporated (SSI); the Northwest Territories Regional Contaminants Committee (NT RCC); the Centre de Toxicologie du Québec (CTQ); the Institut National de Santé Publique du Québec (INSPQ); the Natural Sciences and Engineering Research Council of Canada (NSERC) and the University of Waterloo. This work represents an ongoing collaboration between researchers at the University of Waterloo (Brian Laird, Heidi Swanson, Mylène Ratelle, Kelly Skinner, Rhona Hanning, Shannon Majowicz, Ken Stark), Trent University (Chris Furgal), University of Montréal (Michèle Bouchard), Washington State University (Amanda Boyd), the Dehcho Aboriginal Aquatic Resources and Ocean Management (George Low) and the Sahtú Renewable Resources Board (Deborah Simmons). We would like to thank all community leaders, participants and local coordinators in the Dehcho and Sahtú Region for making this work possible. Financial support: Funding for this work was provided primarily by the Northern Contaminants Program (NCP), Crown Indigenous Relations and Northern Affairs Canada (CIRNAC) (B.L., grant number HH-10). Additional support was received from a Global Water Futures (GWF) sub-grant (B.L and K.S., grant number 214487), Northern Scientific Training Program (NSTP), the Canada Research Chair in Nutritional Lipidomics and the University of Waterloo. Supplemental funding was obtained from the Population Biomonitoring Section (Healthy Environments and Consumer Safety Branch) of Health Canada. These funders had no role in the design, analysis or writing of this article. Conflict of interest: None. Authorship: L.H. and M.R. analysed the data and wrote the main text. M.R. led the fieldwork implementation, B.D.L. designed the concept and served as principal investigator of the project. K.S. assisted with the development of the survey and provided technical support during the project. All the authors contributed with ideas and comments and reviewed the paper. All authors read and approved the final manuscript. Ethics of human subject participation: The current study was conducted according to the guidelines laid down in the Declaration of Helsinki and all procedures involving research study participants were approved by the following ethics committees: The University of Waterloo Research Ethics Committee (\#20173, \#20950, \#30543), the Stanton Territorial Health Authority for Human Research (29/12/2015) and the Aurora Research Institute (\#15560, \#15775, \#15966, \#15977, \#16021). Health Canada (REB 2016-0022). Participants provided free consent. Written informed consent was obtained from all subjects.

\section{Supplementary material}

For supplementary material accompanying this paper visit https://doi.org/10.1017/S1368980021000021

\section{References}

1. Nakano T, Fediuk K, Kassi N et al. (2005) Dietary nutrients and anthropometry of Dene/Metis and Yukon children. Int J Circumpolar Health 64, 147-156.

2. Berti PR, Receveur O, Chan HM et al. (1998) Dietary exposure to chemical contaminants from traditional food among adult Dene/Metis in the Western Northwest Territories, Canada. Environ Res 76, 131-142.

3. Kuhnlein HV \& Receveur O (2007) Local cultural animal food contributes high levels of nutrients for Arctic Canadian indigenous adults and children. J Nutr 137, 1110-1114.

4. Kuhnlein HV, Receuver O, Soueida R et al. (2004) Arctic indigenous peoples experience the nutrition transition with changing dietary patterns and obesity. J Nutr 124, 1447-1453.

5. Environment Natural Resources (2015) Country food use in NWT ecozones. https://www.enr.gov.nt.ca/en/state-envir onment/183-country-food-use-nwt-ecozones (accessed February 2020).

6. Wesche SD \& Chan HM (2010) Adapting to the impacts of climate change on food security among inuit in the Western Canadian Arctic. EcoHealth 7, 361-373.

7. Kuhnlein HV, Receveur O \& Chan HM (2001) Traditional food systems research with Canadian indigenous peoples. Int J Circumpolar Health 60, 112-122.

8. Receveur O, Boulay M, Mills C et al. (1996) Variance in food use in Dene/Métis Communities. Technical report. Centre for Indigenous Peoples' Nutrition and Environment (CINE), McGill.

9. Ratelle M, Laird M, Majowicz S et al. (2018) Design of a human biomonitoring community-based project in the Northwest Territories Mackenzie Valley, Canada, to investigate the links between nutrition, contaminants and country foods. Int J Circumpolar Health 77, 1510714.

10. Ratelle M, Skinner K, Laird MJ et al. (2018) Implementation of human biomonitoring in the Dehcho region of the Northwest Territories, Canada (2016-2017). Arch Public Health 76, 73.

11. Ratelle M, Skinner K, Packull-McCormick S et al. (2020) Food frequency questionnaire assessing traditional food consumption in Dene/Métis communities, Northwest Territories, Canada. Int J Circumpolar Health 79, 1760071.

12. Batal M, Gray-Donald K, Kuhnlein HV et al. (2005) Estimation of traditional food intake in indigenous communities in Denendeh and the Yukon. Int J Circumpolar Health 64, 46-54.

13. Gagne D, Blanchet R, Lauziere J et al. (2012) Traditional food consumption is associated with higher nutrient intakes in Inuit children attending childcare centres in Nunavik. Int J Circumpolar Health 71, 18401.

14. Hanning RM, Royall D, Toews JE et al. (2009) Web-based Food Behaviour Questionnaire: validation with grades six to eight students. Can J Diet Pract Res 70, 172-178.

15. Kolahdooz F, Butler L, Lupu M et al. (2014) Assessment of dietary intake among inuvialuit in Arctic Canada using a locally developed quantitative Food Frequency Questionnaire. J Am Coll Nutr 33, 147-154.

16. Kuhnlein HV, Receveur O, Soueida R et al. (2008) Unique patterns of dietary adequacy in three cultures of Canadian Arctic indigenous peoples. Public Health Nutr 11, 349-360.

17. Seabert TA, Pal S, Pinet BM et al. (2014) Elevated contaminants contrasted with potential benefits of omega-3 fatty acids in wild food consumers of two remote first nations communities in northern Ontario, Canada. PLoS One 9, e90351.

18. Cooper JE (1995) The role of birds in sustainable foodproduction. Biodivers Conserv 4, 266-280.

19. Sahtu Renewable Resources Board (2020) Colville Lake. https://www.srrb.nt.ca/index.php?option=com_content\& view $=$ article $\& i d=181: \mathrm{k}$-ahbamntue-colville-lake $\&$ catid $=$ 99:the-sahtu\&Itemid=689 (accessed March 2020). 
20. Geldenhuys G, Hoffman LC \& Muller N (2013) Gamebirds: a sustainable food source in Southern Africa? Food Secur 5 , 235-249.

21. Kuhnlein HV, Appavoo D, Morrison N et al. (1994) Use and nutrient composition of Traditional Sahtú (Hareskin) Dene/ Métis Foods. J Food Compost Anal 7, 144-157.

22. Usher PJ (2002) Inuvialuit use of the beaufort sea and its resources, 1960-2000. Arctic 55, 18-28.

23. Jarvenpa R \& Brumbach HJ (2015) Ethnoarchaeological collaborations: hunting societies, interethnic relations, and gender in the Northern Latitudes, Part II. Ethnoarchaeol J Archaeol Ethnographic Exp Stud 7, 58-75.

24. Rosol R, Powell-Hellyer S \& Chan HM (2016) Impacts of decline harvest of country food on nutrient intake among Inuit in Arctic Canada: impact of climate change and possible adaptation plan. Int J Circumpolar Health $\mathbf{7 5}$, 31127-31127.

25. Guyot M (2006) Impacts Climate Change Traditional Food Security in Aboriginal Communities in Northern Canada. Montreal: McGill University.

26. Crick HQP (2004) The impact of climate change on birds. Ibis 146, 48-56.

27. Aubry LM, Rockwell RF, Cooch EG et al. (2013) Climate change, phenology, and habitat degradation: drivers of gosling body condition and juvenile survival in lesser snow geese. Glob Chang Biol 19, 149-160.

28. Gwinner E (1996) Circannual clocks in avian reproduction and migration. Ibis 138, 47-63.

29. Olsen B, Munster VJ, Wallensten A et al. (2006) Global patterns of Influenza A virus in wild birds. Science 312, 384.

30. Liberda E, Meldrum R, Charania N et al. (2017) Avian influenza prevalence among hunter-harvested birds in a remote First Nation community. Rural Remote Health 17, 1-6.

31. Health Canada (2017) Highly Pathogenic Avian Influenza. https://www.canada.ca/en/environment-climate-change/ services/migratory-game-bird-hunting/highly-pathogenicavian-influenza.html (accessed March 2020).

32. Jung J \& Skinner K (2017) Foodborne and waterborne illness among Canadian Indigenous populations: a scoping review. Can Communicable Dis Rep 43, 7-13.

33. Tsuji LJS, Martin ID, Martin ES et al. (2007) Spring-harvested game birds from the western James Bay region of northern Ontario, Canada: organochlorine concentrations in breast muscle. Sci Total Environ 385, 160-171.

34. Thomas VG \& Guitart R (2018) Lead use in hunting and fishing-consequences to birdlife, humans, and the environment. In The Encyclopedia of the Anthropocene 5, pp. 177180 [DA DellaSala and MI Goldstein, editors]. Oxford: Elsevier.

35. Kreager N, Wainman BC, Jayasinghe RK et al. (2008) Lead pellet ingestion and liver-lead concentrations in upland game birds from southern Ontario, Canada. Arch Environ Contam Toxicol 54, 331-336.

36. Ratelle M, Packull-McCormick S, Bouchard M et al. (2020) Human biomonitoring of metals in sub-Arctic Dene communities of the Northwest Territories, Canada. Environ Res 190, 110008.

37. Receveur O, Boulay M \& Kuhnlein HV (1997) Decreasing traditional food use affects diet quality for adult Dene/Metis in 16 communities of the Canadian Northwest Territories. J Nutr 127, 2179-2186.

38. Belinsky DL \& Kuhnlein HV (2000) Macronutrient, mineral, and fatty acid composition of canada goose (branta canadensis): an important traditional food resource of the Eastern James Bay Cree of Quebec. J Food Compost Anal 13, 101-115.

39. Tsuji LJ \& Nieboer E (1999) A question of sustainability in Cree harvesting practices: the seasons, technological and cultural changes in the western James Bay region of northern Ontario, Canada. Can J Native Stud 19, 169-192. 